\title{
Outbreak of stem bleeding in coconuts caused by Thielaviopsis paradoxa in Sergipe, Brazil
}

\author{
Dulce R.N. Warwick \& Edson E.M. Passos \\ Embrapa Tabuleiros Costeiros, 49001-970, Aracaju, SE, Brazil \\ Author for correspondence: Dulce R.N. Warwick, e-mail: dulce@cpatc.embrapa.br
}

\begin{abstract}
In February of 2004, at "Platô de Neópolis", Sergipe, Brazil, about 50 coconut plants were found bearing symptoms of a disease not yet recorded in Brazil. The trunk of diseased plants exhibited a reddish-brown or rust-colored liquid bleeding from scars. Inside the stem, the tissues under the lesions were rotting and turned brownish-yellow to black. Diseased palms had reduced growth and three to four months after the first symptoms were noticed the affected plants died. A fungus was isolated from diseased tissues and identified as Thielaviopsis paradoxa. Healthy plants were inoculated with the fungus and lesions developed demonstrating the pathogenicity of the isolate.
\end{abstract}

Keywords: Ceratocystis paradoxa, Chalara, Cocos nucifera.

\section{RESUMO}

Ataque de resinose do coqueiro causada por Thielavopsis paradoxa em Sergipe, Brasil

Em fevereiro de 2004, na localidade "Platô de Neópolis", Sergipe, Brasil, cerca de 50 plantas foram observadas apresentando sintomas de uma doença ainda não registrada no Brasil. O estipe afetado apresentava um líquido avermelhado que saía de rachaduras. Estas áreas apresentando rachaduras ao serem dissecadas tinham extensas porções de tecido em decomposição. As plantas apresentavam crescimento reduzido e de três a quatro meses após o aparecimento dos primeiros sintomas ocorria a morte das plantas. Um fungo foi isolado dos tecidos doentes e identificado como Thielaviopsis paradoxa. Plantas sadias quando inoculadas com o fungo tiveram desenvolvimento de lesões, o que demonstrou a patogenicidade do fungo isolado.

Palavras-chave: Ceratocystis paradoxa, Chalara, Cocos nucifera.

The coconut tree (Cocos nucifera L.) is widely grown along the Northeastern coast of Brazil as well as in other areas of Brazil. There is a large and increasing demand for immature coconuts that are harvested and marketed for consumption of their liquid endosperm (coconut water). This is mostly supplied by dwarf variety plantations and average productivity has been limited in Brazil to around 3,400 fruits/hectare because of limited rainfall levels, pests and diseases (Cuenca, 1994). Warwick et al. (2004) noted the occurrence of what appeared to be a novel coconut disease for Brazil at Platô de Neópolis (State of Sergipe). About 50 coconut plants were observed to have symptoms of stem bleeding, a disease that was previously unrecorded in Brazil.

The affected trunk areas exhibited dark discoloration and a reddish-brown or rust-colored liquid bleeding from different points (Figure 1). Diseased palms had reduced growth and a gradual but progressive necrosis of the lower pinnate leaf toward the midribs. Inside the stem, the tissues under the lesions were rotting and became brownish-yellow to black. Eventually the affected plants died. In every case, the plant showing symptoms was also being attacked by the weevil Rhynchophorus palmarum L. No attempt was made to treat the diseased plants, which died within 3-4 months of the observation of the early stem symptoms. Other biotic diseases that may be lethal to coconut palms in Brazil are: red ring, caused by the nematode Bursaphlelenchus cocophilus (Warwick \& Bezerra, 1992); hartrot, caused by Phytomonas sp., a flagellate protozoa (Renard, 1989), and eye-rot caused by two species of Phytophthora (Quillec \& Renard, 1984).

In India, plants showing a similar disease were proven to be attacked by Thielaviopsis paradoxa (De Seynes) Höhn. (anamorphic Ceratocystidaceae). The studies in India showed that inoculation of healthy coconut plants with isolates obtained from diseased plants resulted in rusty brown discoloration of the bark within 2-8 weeks, followed by the oozing of a brownish liquid from stems. Re-isolation of T. paradoxa was made from such diseased tissues (Nambiar et al., 1986). Stem bleeding of coconut is known to occur in nearly all the countries which grow coconut (Ohler, 1964). The disease was first reported from Sri Lanka (Petch, 1906) and serious infection was found to lead to reduced yield (Nambiar \& Sastry, 1988). In Indonesia stem bleeding causes severe damage to PB121 hybrid and affects yield (Kartika et al., 1984) The 


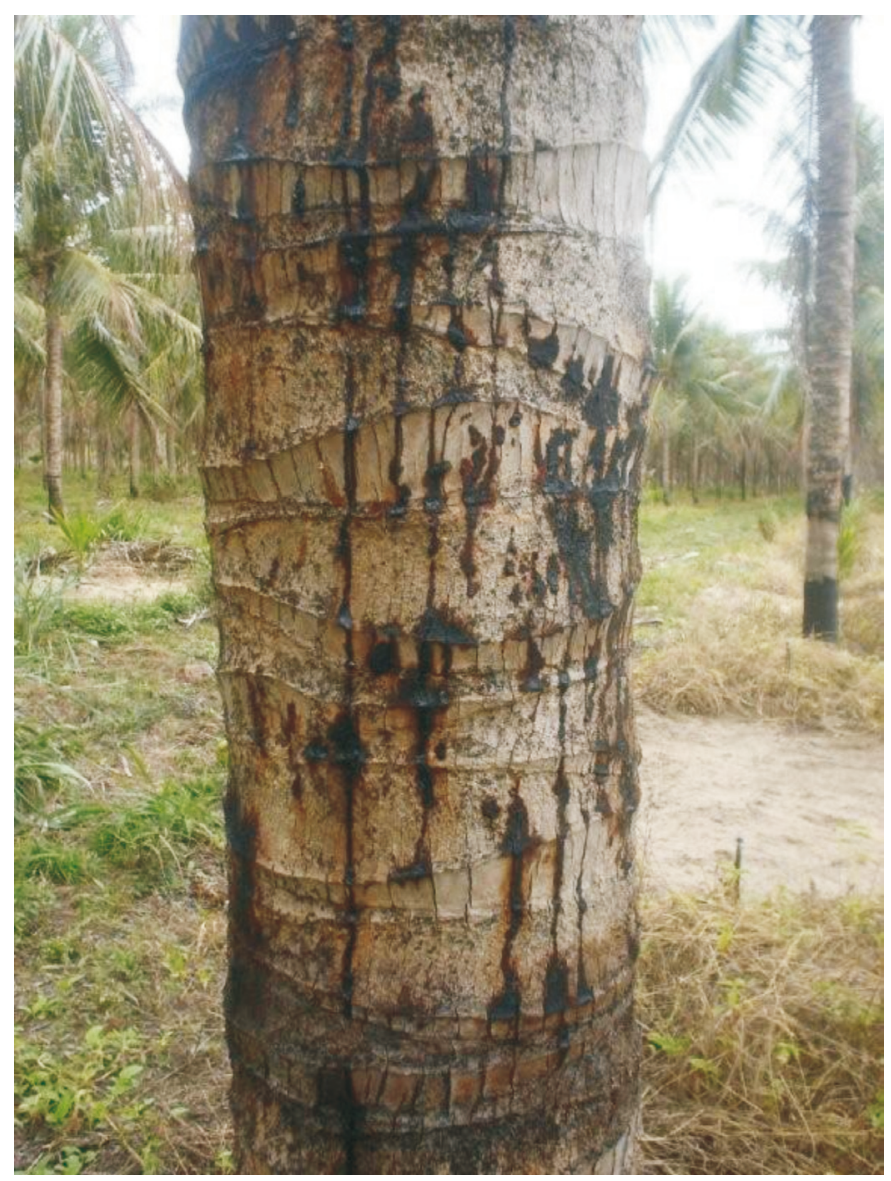

FIGURE 1 - Exudation of reddish-brown liquid through cracks on a coconut trunk.

teleomorph of T. paradoxa, Ceratocystis paradoxa (Dade) C. Moreau, has already been recorded attacking coconut plants in Amazonas State, Brazil (Alves \& Lourd, 1985), but only causing immature fruit drop. Later, the same fungus was reported from Sergipe (Franco \& Franco Filho, 1986), causing inflorescence necrosis and affecting coconut production. Further studies showed reduction of the photosynthetic activity on diseased plants, probably owing to a reduction in the activity of absorption and/ or translocation of nutrients and water (Warwick et al., 2004).

Tissue fragments were removed from the lesion margins, surface-sterilized in $70 \%$ ethanol, followed by $45 \mathrm{sec}, 0,65 \%$ sodium hypochlorite and plated onto Petri dishes (9-mm-diameter) with potato-dextrose agar. Cultures were routinely incubated at $23-25^{\circ} \mathrm{C}$ on a laboratory bench. A 5-mm-diameter plug taken from the culture margin was transferred to PDA for fungus purification. Morphology of such isolates was typical of $T$. paradoxa. The fungus had pale brown mycelium and straight conidiophores up to 250 $\mu \mathrm{m}$ in length. Each had a terminal phialide. The conidia were cylindrical colorless to pale brown $(7-15 \times 2.5$ $6 \mu \mathrm{m})$. The chlamydospores were borne terminally in chains, smooth, oval pale-brown to brownish-black (9-25 x 6-15 $\mu \mathrm{m})($ Nag Raj \& Kendrick, 1975).

Pathogenicity of the fungus was tested by inoculating 10 three-year-old, 12-leaved green dwarf coconuts in a screen-house. Inoculum consisted of 5-mm-diameter plugs taken from a 7-day-old T. paradoxa culture grown on PDA. The plugs were placed on healthy trunks, rachis and folioles which were either intact or wounded. Wounds were made with a sterilized cork borer. The sites of the inoculations were wrapped with plastic tape to prevent desiccation; the experiment was repeated 3 times. Controls received sterile PDA. The isolate was deposited in Coleção de Fungos Maria Menezes Recife PE, as strain CMM 1588.

Characteristic rusty-brown lesions appeared only on plants that were inoculated with the fungus and only on wounded trunks or rachis but not on healthy or wounded leaflets, two weeks after inoculation. A brownish liquid oozed from the points of inoculation. Controls did not show any signs of disease development. T. paradoxa was re-isolated from the diseased tissues. This fungus is known to be a polyphagous pathogen that enters the plants through wounds provoked by various causes that may be either biotic or abiotic in origin. 
Attempts to control spread of the disease at the site where this record was made failed to curtail epiphytotics, despite the following actions: interrupting irrigation, controlling the insect pest $R$. palmarum, removing diseased tissues from infected trees, applying fungicide sprays and removing severely diseased plants from the area. The spread of the infection is still advancing. An account of the situation in that area (December 2007) reports that in a single plantation of 6000 plants, approximately 2000 coconut plants showed disease symptoms (J.A. Santos Júnior, pers. comm.), a worrying situation.

\section{ACKNOWLEDGMENTS}

The authors would like to thank José Luiz Bezerra for his help with the identification of the fungus.

\section{REFERENCES}

Alves MLB, Lourd M (1985) Podridão negra de frutos de coco causada por Ceratocystis paradoxa em Manaus AM. Fitopatologia Brasileira 10:233.

Cuenca MAG (1994) Importância econômica do coqueiro. In: Ferreira JMS, Warwick DRN, Siqueira LA (Eds.) Cultura do coqueiro no Brasil. Aracaju SE. EMBRAPA SPI.

Franco EA, Franco Filho E (1986) O enegrecimento da inflorescência do coqueiro. Fitopatologia Brasileira 11:311. Resumo.
Kartika D, Soebagio FS, Turner PD, Breure CJ (1984) Severe stem bleeding and frond fracture of MAWA hybrid coconut in North Sumatra. Paper 51, International Conference on Cocoa and Coconut, Malaysia.

Nag Raj TR, Kendrick B (1975). A monograph of Chalara and allied genera. Waterloo, Canada. Wilfrid Laurier University Press.

Nambiar KKL, Joshi Y, Venugopal MN, Mohan RC (1986) Stem bleeding disease of coconut: reproduction of symptoms by inoculation with Thielaviopsis paradoxa. Journal of Plantation Crops 14:130-133.

Nambiar KKL, Sastry K. RC (1988) Stem bleeding disease of coconut: reproduction of symptoms by inoculation with Thielaviopsis paradoxa. Journal of Plantation Crops 14:130-133.

Ohler JG (1964) Coconut, Tree of life. Rome. Food and Agriculture Organization.

Petch T (1906) Diseases of the coconut palm. Tropical Agriculturist 27:489-491.

Quillec G, Renard JL (1984) Phytophthora rot of coconut. Oléagineux 39:143-145.

Renard JL (1989) Le Hartrot du cocotier: caractérisation et moyens du lutte. Oléagineux 44:475-484.

Warwick DRN, Bezerra APT (1992) Possible root transmission of the red ring nematode (Rhadinaphelenchus cocophilus) to coconut palm. Plant Disease 76:809-811.

Warwick DRN, Ferreira JMS, Melo EEP (2004) Ocorrência de resinose do estipe do coqueiro provocada por Chalara paradoxa em Sergipe. Fitopatologia Brasileira 29 (Supl.):413. 